\title{
Outdoor Air Quality and Antibiogram Characteristics of Bacterial Isolates of Akure City Abattoirs, Nigeria
}

\author{
Olubukola Olayemi Olusola-makinde \\ Department of Microbiology, School of Sciences, Federal University of Technology, Akure, Nigeria. \\ * Corresponding author email: ooolusola-makinde@futa.edu.ng
}

Received: 10 October 2019 / Revised: 14 November 2019 / Accepted: 16 November 2019 / Published: 16 November 2019

\section{ABSTRACT}

\begin{abstract}
Air sampling of Onyearugbulem and FUTA abattoirs was carried out to evaluate their quality. Air sampling was done using the open-settling method on general and selective agar media of the gutter, sleeping bench, slaughtering floor dumpsite, slaughtering table and roof of the abattoirs. Using standard methods, Presumptive identification of the bacterial isolates was carried out. An array of ten (10) conventional antibiotics was used to assay the antibiotic susceptibility characteristics of the bacterial isolates. Multiple antibiotic sensitivity index (MARI) was determined for isolated bacteria. At Onyearugbulem abattoir, the total Escherichia coli count ranged from $3.6 \times 10 \mathrm{cfu} / \mathrm{ml}$ from the gutter and slaughtering table to $6.5 \times 10 \mathrm{cfu} / \mathrm{ml}$ from the slaughtering floor, while the total bacterial count ranged from $1.34 \times 10^{2} \mathrm{cfu} / \mathrm{ml}$ from dumpsite to $2.55 \times 10^{2} \mathrm{cfu} / \mathrm{ml}$ from the gutter, the total coliform count ranged from $2.8 \times 10 \mathrm{cfu} / \mathrm{ml}$ from slaughtering floor to $4.1 \times 10 \mathrm{cfu} / \mathrm{ml}$ from sleeping bench. Several bacteria were presumptively isolated. These include: Micrococcus sp., Bacillus sp., Staphylococcus aureus, Escherichia coli, Proteus sp., Enterobacter aerogenes and Aeromonas sp. Ciprofloxacin (10 $\mu \mathrm{g})$ had an inhibitory effect on all the Gram positive bacterial isolates with the highest inhibitory activity on $S$. aureus at 24.00 $\mathrm{mm}$, and the Gram negative bacteria with the highest inhibitory activity on E. coli at $21.00 \mathrm{~mm}$. Micrococcus sp. had the highest MARI of 0.8. These findings reveal the presence of multiple-antibiotic resistant bacteria in Onyearugbulem and FUTA abattoirs' atmosphere. There is therefore need for routine environmental sanitation of the slaughterhouses.
\end{abstract}

Keyword: abattoir, air quality, bacterial occurrence, conventional antibiotics, multiple antibiotic resistance

\section{Introduction}

Clean air is a chief essential for good health [1]. Air is a mixture of gases. The common term, air, is accrued to the atmospheric gases involved in respiration and photosynthesis. In constitution, dry air consists of argon $(0.93 \%)$, carbon dioxide $(0.039 \%)$, nitrogen $(78.9 \%)$, oxygen $(20.95 \%)$, and a slight quantity of water vapour, averagely about $1 \%$ at sea level and $0.4 \%$ on the whole atmosphere [2]. There are five major layers in earth atmosphere; they are exosphere, mesosphere, stratosphere, thermosphere and troposphere. Dust containing microorganisms and minerals can occur as aerosols in unfiltered air sample which are substances of natural derivation in different minute amount [3]. There are lots of airborne particles which are responsible for respiratory ailments of humans, causing allergies, asthma and pathogenic infection of the respiratory tract [4]. Air can serve as a transport medium for different organisms that are capable of causing respiratory infections; the likes of Mycobacterium tuberculosis, Mycoplasma sp., Streptococcus sp., Bordetella pertussis, Yersinia pestis are responsible for different airborne diseases [5].

By definition, an abattoir is a physical environment containing the required infrastructure for killing animals, primarily for consumption as food produces. The killing of animals on commercial scale positions important logistical challenges and environmental health issues. Microbial pollution of meat products by air related bacteria and fungi is a significant financial problem in the livestock industries. It has been 
Olubukola Olayemi Olusola-makinde, Int. Ann. Sci.; Vol. 9, Issue 1, pp: 33-40, 2020

inaccurately disputed before that foods get contaminated when in contact with polluted substances, recently, a better understanding is known that additional problems surfaces when food comes in contact with air related bacteria. There are many routes whereby disease-causing airborne bacteria and spoilage microorganisms can be associated with meat products, these include, the slaughtering process, cold storage and processing of meat animals and so on. Microbial contaminants are also referred to as bio aerosols, they consists of bacteria, fungi, and viruses which could be available in the air as solid, or liquid [7].The majority of Gram-negative airborne bacteria commonly associated with abattoirs are from the Enterobacteriaceae and Pseudomonadaceae families while the Grampositive airborne bacteria that are usually are Staphylococcus, Microbacterium, Bacillus and Micrococcus species. Specific pathogenic bacteria usually found in the air sampling areas of the abattoir are Eschericbia coli, Salmonella sp. and Bacillus sp. [8].

Antibiotics are a type of antimicrobials which are used in prevention and treatment of infections. They may either kill or inhibit the growth of bacteria. Several antibiotics are also effective against fungi and protozoan and some are toxic to humans and animals, even when administered and used in the right dosage [9]. Classes of antibiotics include; penicillin such as penicillin and amoxicillin, cephalosporin such as cephalexin, macrolides such as erythromycin, clarithromycin, sulfonamides such as co-trimoxazole and trimetoprim, tetracycline such as tetracycline and doxycline; and aminoglycosides such as gentamicin and tobramicin [10].

Studies have shown the growing concern of airborne diseases, affecting over $25 \%$ of the population in urban areas, and with a predicted estimate of about $50 \%$ of world population to be affected by different disease as a result of human exposure to microorganisms [11]. This development has therefore necessitated the need to evaluate the outdoor air quality of Onyearugbulem and FUTA abattoirs in Akure, being the major abattoirs in the city. This works aims at assessing the bacterial composition of the abattoirs' immediate atmosphere providing information about the occurrence, identity and antibiogram characteristics.

\section{Materials and Methods}

\section{$2.1 \quad$ Isolation and Enumeration of Bacteria}

With major modifications, open plate method of Andualem et al. [1] was used to isolate bacteria from Onyearugbulem and FUTA slaughtering environments. Sterilized agar plates were exposed to different locations for a period of 30 minutes. The agar media employed were Nutrient agar (Biolab), MacConkey agar (Biolab) and Eosin methylene blue agar (Biolab) for the isolation of total bacterial counts, total coliform counts and total E. coli counts respectively. Exposed plates were immediately returned to the Microbiology laboratory of the Federal University of Technology, Akure for incubation at $37{ }^{\circ} \mathrm{C}$ for 24 hours. Different colonies from the agar media were counted using the colony counter and aseptically streaked on freshly prepared nutrient agar. The plates were incubated at $37{ }^{\circ} \mathrm{C}$ for 24 hours, and pure colonies obtained from the subcultured plates were aseptically transferred on well labelled nutrient agar slants and preserved at $4{ }^{\circ} \mathrm{C}$ for further studies.

\subsection{Presumptive identification of bacterial isolates}

The appearance of colonies of the bacterial isolates was well studied and observed according to Olutiola et al. [12]. Colonial and morphological characteristics such as colour, edge, shape, the surface and elevation of the colonies were observed and recorded. The following biochemical tests were carried out on isolates; coagulase, citrate, indole, triple sugar iron and catalase tests. The Gram reaction of each of the bacterial isolates was also carried out.

\subsubsection{Coagulase test}

For the coagulase test, a loopful of 24-hour old pre-cultured bacterial isolate was emulsified in normal saline on grease-free glass slide and an equal volume of plasma was added and mixed together aseptically. Clumps or precipitate in the mixture indicated a positive coagulase test, meaning that the organism produces a coagulase 
Outdoor Air Quality and Antibiogram Characteristics of Bacterial Isolates of Akure City Abattoirs, Nigeria

enzyme while the absence of clumps indicated a negative result [13].

\subsubsection{Citrate test}

The citrate test detects the ability of an organism to use citrate as the sole source of carbon and energy. Simmon's citrate agar was prepared according to the manufacturer's instruction, and the agar was aseptically poured into each of the test tubes and allowed to gel. Bacterial isolates were aseptically inoculated into the different labelled test tubes. All slants were incubated at 37 ${ }^{\circ} \mathrm{C}$ for 24 hours. The presence of growth on the surfaces of the slants which was accompanied by blue colouration indicated a positive result, while no growth and the medium remaining green in colour confirmed a negative test [14].

\subsubsection{Indole test}

The indole test is a biochemical assay carried out to evaluate the capacity of bacterial cells in the conversion of tryptophan to indole. Peptone broth was prepared into different test tubes and autoclaved at $121{ }^{\circ} \mathrm{C}$ for 15 minutes. After sterilization, the test tubes were inoculated with different bacterial isolates and incubated at $37{ }^{\circ} \mathrm{C}$ for 24 hours. After incubation, 2 drops of Kovac's reagent was pipette into each test tube containing peptone broth and organism. The test tubes were made to stand for 20 minutes, after which different results were seen. Red colouration at the surface of broth confirmed indole formation, thus a positive result while yellow colouration indicated no indole formation and a negative test result [13].

\subsubsection{The Triple sugar iron test}

Triple sugar iron test was done to distinguish between Gram negative enteric bacilli due to their ability to ferment carbohydrate and reduce hydrogen sulphide [14]. Triple sugar iron (TSI) agar contains $\mathrm{pH}$ sensitive dye (which could be phenol red), $1 \%$ lactose, $1 \%$ sucrose, $0.1 \%$ glucose as well as sodium thiosulfate and ferrous sulphate. Triple Sugar Iron slants were prepared and inoculated with the bacterial isolates. The slants were incubated for 24 hours at $37{ }^{\circ} \mathrm{C}$. Gas formation and acid production accompanied by $\mathrm{H}_{2} \mathrm{~S}$ were observed. Acid production was noticeable through colour change [14].

\subsubsection{Catalase test}

For the catalase test, a loopful of 24-hour old preculture of bacterial isolates was aseptically placed on different grease free glass slides with the aid of sterile wooden stick. Several drops of hydrogen peroxide were placed on the slides and rocked. Rapid evolution of oxygen as evidenced by bubbling was recorded as the positive result, while the negative result was recorded for isolates that had no bubble production [12].

\subsubsection{Gram Staining}

For Gram reaction, the staining procedure began with the preparation of a smear from a 24-hour old culture on grease-free labelled glass slides. The smear on each of the slides was heat-fixed by passing the backsides of the slides gently over the flame. The grease-free glass slides were stained with crystal violet and were left for 60 seconds, after 60 seconds the slides were washed with water, the slides were then stained with iodine and left for another 60 seconds, after which they were flooded with water. Ethanol was added to each slide and left for 30 seconds before rinsing with water. The slides were counter-stained with safranin and were left for 60 seconds, after which they were rinsed with water and allowed to air dry. A drop of immersion oil was added to each of the stained slides and each slide was examined under oil immersion of the microscope [12].

\subsection{Antibiotic sensitivity pattern of bacterial isolates}

The antibiotic sensitivity test was carried out as described by the guiding principles of Clinical and Laboratory Standard Institute [15] using the disc diffusion test which was experimented on Muller Hinton agar medium. Briefly, peptone water was pipette into different test tubes and sterilized at $121^{\circ} \mathrm{C}$ for 15 minutes. Then, bacterial culture was inoculated into the test tubes containing sterile peptone water, $0.1 \mathrm{ml}$ of the solution was pipette on sterile gelled agar plates and allowed to wait for 20 minutes. A panel of 10 conventional antibiotics including amoxicillin $(30 \mu \mathrm{g})$, sparfloxacin $(10 \mu \mathrm{g})$, gentamicin (10 $\mu \mathrm{g})$, pefloxacin $(30 \mu \mathrm{g})$, chloramphenicol $(30 \mu \mathrm{g})$, streptomycin $(10 \mu \mathrm{g})$, ciprofloxacin (10 $\quad \mu \mathrm{g})$, sulfamethoxazole/trimethoprim (30 $\mu \mathrm{g})$, 
Olubukola Olayemi Olusola-makinde, Int. Ann. Sci.; Vol. 9, Issue 1, pp: 33-40, 2020

ofloxacin $(10 \mu \mathrm{g})$ and amoxicillin/clavulanic acid $(30 \mu \mathrm{g})$ were used for this study. Antibiotic discs were aseptically planted on the agar plates using sterile forceps. The plates were incubated at $37^{\circ} \mathrm{C}$ for 24 hours. The zones of inhibition observed around the discs were measured in millimeters and recorded accordingly.

\subsection{Multiple Antibiotic Resistance Index}

Multiple antibiotics resistance index (MARI) was determined using ensuing formulation according to Mahroop Raja and John [16]:

MAR Index $=$ total number of antibiotics the isolate was resistant to

total number of antibiotics studied

\section{Results}

\subsection{Total counts of bacteria associated with Onyearugbulem and FUTA abattoirs}

Table 1 shows the total count of bacteria isolated from different sampling points of Onyearugbulem abattoir. The sampling points were gutter, sleeping benches, slaughter floor, slaughtering table and dump site.

Table 1: Total counts of bacterial isolates from Onyearugbulem Abattoir

\begin{tabular}{|l|c|c|c|}
\hline \multicolumn{1}{|c|}{ Sampling } & $\begin{array}{c}\text { Total } \\
\text { Point } \\
\text { Bacterial } \\
\text { Count } \\
(\text { CFU/ml })\end{array}$ & $\begin{array}{c}\text { Total } \\
\text { Coliform } \\
\text { Count } \\
(\mathrm{CFU} / \mathrm{ml})\end{array}$ & $\begin{array}{c}\text { Total } \\
\text { Escherichia } \\
\text { coli } \text { Count } \\
(\mathrm{CFU} / \mathrm{ml})\end{array}$ \\
\hline Gutter & $2.55 \times 10^{1}$ & $3.5 \times 10^{1}$ & $3.6 \times 10^{1}$ \\
\hline $\begin{array}{l}\text { Sleeping } \\
\text { bench }\end{array}$ & $1.56 \times 10^{2}$ & $4.1 \times 10^{1}$ & $4.3 \times 10^{1}$ \\
\hline $\begin{array}{l}\text { Slaughter } \\
\text { floor }\end{array}$ & $1.42 \times 10^{2}$ & $2.8 \times 10^{1}$ & $6.5 \times 10^{1}$ \\
\hline Dump site & $1.34 \times 10^{2}$ & $3.2 \times 10^{1}$ & $3.7 \times 10^{1}$ \\
\hline $\begin{array}{l}\text { Slaughtering } \\
\text { table }\end{array}$ & $1.50 \times 10^{2}$ & $3.9 \times 10^{1}$ & $3.6 \times 10^{1}$ \\
\hline
\end{tabular}

Table 2 shows the total count of bacteria isolated from different sampling points of FUTA abattoir. The sampling points were roof, the slaughter table and the slaughter floor. At Onyearugbulem abattoir, the total Escherichia coli count ranged from $3.6 \times 10 \mathrm{cfu} / \mathrm{ml}$ from the gutter and slaughtering table to $6.5 \times 10 \mathrm{cfu} / \mathrm{ml}$ from the slaughtering floor, while the total bacterial count ranged from $1.34 \times 10^{2} \mathrm{cfu} / \mathrm{ml}$ from dumpsite to $2.55 \times 10^{2}$ $\mathrm{cfu} / \mathrm{ml}$ from the gutter, the total coliform count ranged from $2.8 \times 10 \mathrm{cfu} / \mathrm{ml}$ from slaughtering floor to $4.1 \times 10 \mathrm{cfu} / \mathrm{ml}$ from sleeping bench.

Table 2: Total counts of bacterial isolates from FUTA Abattoir

\begin{tabular}{|l|c|c|c|}
\hline \multicolumn{1}{|c|}{$\begin{array}{c}\text { Sampling } \\
\text { Point }\end{array}$} & $\begin{array}{c}\text { Total } \\
\text { Bacterial } \\
\text { Count } \\
(\mathrm{CFU} / \mathrm{ml})\end{array}$ & $\begin{array}{c}\text { Total } \\
\text { Coliform } \\
\text { Count } \\
(\mathrm{CFU} / \mathrm{ml})\end{array}$ & $\begin{array}{c}\text { Total } \\
\text { Escherichia } \\
\text { coli } \text { Count } \\
(\mathrm{CFU} / \mathrm{ml})\end{array}$ \\
\hline Roof & $6.0 \times 10^{1}$ & $4.1 \times 10^{1}$ & $5.7 \times 10^{1}$ \\
\hline $\begin{array}{l}\text { Slaughter } \\
\text { table }\end{array}$ & $5.2 \times 10^{1}$ & $3.4 \times 10^{1}$ & $5.8 \times 10^{1}$ \\
\hline $\begin{array}{l}\text { Slaughter } \\
\text { floor }\end{array}$ & $1.56 \times 10^{2}$ & $4.3 \times 10^{1}$ & $7.2 \times 10^{1}$ \\
\hline
\end{tabular}

\subsection{Colonial, morphological and biochemical characteristics of bacterial isolated from Onyearugbulem and FUTA abattoirs}

The morphological characteristics of the bacteria that were isolated from Onyearugbulem and FUTA abattoirs are contained in Table 3. Shape, colour, and elevation were observed. Table 4 shows the various biochemical tests carried out on the isolated bacteria. The probable bacterial isolates include; Micrococcus Sp, Bacillus Sp, Staphylococcus aureus Escherichia coli, Proteus Sp, Enterobacter aerogenes and Aeromonas Sp. Tables 5 and 6 show the occurrence of bacterial isolates from Onyearugbulem and FUTA abattoirs.

Table 3: Morphological characteristics of bacterial isolates

\begin{tabular}{|c|c|c|c|}
\hline Shape & Colour & Elevation & $\begin{array}{l}\text { Probable } \\
\text { Bacteria }\end{array}$ \\
\hline Cocci & $\begin{array}{l}\text { Deep } \\
\text { yellow }\end{array}$ & Raised & $\begin{array}{c}\text { Staphylococcus } \\
\text { aureus }\end{array}$ \\
\hline Cocci & $\begin{array}{l}\text { Light } \\
\text { yellow }\end{array}$ & Raised & $\begin{array}{c}\text { Micrococcus } \\
\text { luteus }\end{array}$ \\
\hline Rod & Cream & Raised & Bacillus spp \\
\hline Rod & Yellow & Raised & $\begin{array}{l}\text { Enterobacter } \\
\text { aerogenes }\end{array}$ \\
\hline Rod & $\begin{array}{l}\text { Light } \\
\text { yellow }\end{array}$ & Flat & Aeromonas spp \\
\hline Rod & Cream & Flat & $\begin{array}{l}\text { Proteus } \\
\text { mirabilis }\end{array}$ \\
\hline Rod & Cream & Raised & Escherichia coli \\
\hline Rod & Cream & Flat & Proteus vulgaris \\
\hline
\end{tabular}


Outdoor Air Quality and Antibiogram Characteristics of Bacterial Isolates of Akure City Abattoirs, Nigeria

Table 4: Biochemical characteristics of bacterial isolates

\begin{tabular}{|c|c|c|c|c|c|c|c|}
\hline Organisms & Catalase & Coagulase & Citrate & Indole & TSI & $\begin{array}{l}\text { Hydrogen } \\
\text { sulphide } \\
\text { formation }\end{array}$ & $\begin{array}{l}\text { Gram } \\
\text { stain }\end{array}$ \\
\hline Staphylococcus aureus & +ve & +ve & +ve & - ve & A \& $\mathrm{G}$ & - ve & +ve \\
\hline Micrococcus luteus & +ve & - ve & -ve & - ve & - ve & -ve & +ve \\
\hline Bacillus spp & +ve & - ve & +ve & +ve & A \& $\mathrm{G}$ & -ve & +ve \\
\hline Enterobacter aerogenes & +ve & -ve & +ve & -ve & A \& $\mathrm{G}$ & -ve & +ve \\
\hline Aeromonas spp & +ve & - ve & +ve & - ve & A \& $\mathrm{G}$ & +ve & -ve \\
\hline Proteus mirabilis & +ve & - ve & -ve & - ve & $\mathrm{A} \& \mathrm{G}$ & +ve & +ve \\
\hline Escherichia coli & +ve & -ve & +ve & -ve & $\mathrm{A} \& \mathrm{G}$ & -ve & $-v e$ \\
\hline Proteus vulgaris & +ve & - ve & -ve & - ve & $A \& G$ & +ve & - ve \\
\hline
\end{tabular}

KEY $:-v e=$ Negative reaction, $+\mathrm{ve}=$ Positive reaction, $\mathrm{A} \& \mathrm{G}=$ Acid $\&$ Gas Production, $\mathrm{A}=$ Acid Production, $\mathrm{TSI}=$ Triple sugar iron test

Table 5: Occurrence of bacterial isolates from Onyearugbulem abattoir

\begin{tabular}{|c|c|}
\hline Areas of the abattoir sampled & Types of organisms isolated \\
\hline Slaughter slab & $\begin{array}{l}\text { Staphylococcus aureus, Proteus vulgaris, Bacilus spp, } \\
\text { Escherichia coli, Aeromonas spp }\end{array}$ \\
\hline Sleeping bench & Enterobacter aerogenes, Proteus mirabilis \\
\hline Slaughtering table & $\begin{array}{l}\text { Staphylococcus aureus, Bacillus spp, Escherichia coli, } \\
\text { Proteus mirabilis }\end{array}$ \\
\hline Dump site & Escherichia coli, Aeromonas spp, Bacillus spp \\
\hline Gutter edge & Enterobacter aerogenes \\
\hline
\end{tabular}

Table 6: Occurrence of bacterial isolates from FUTA abattoir

\begin{tabular}{|l|l|}
\hline Areas of the Abattoir Sampled & Types of Organisms Isolated \\
\hline Slaughtering slab & Staphylococcus aureus, Aeromonas spp \\
\hline Roof top & Escherichia coli \\
\hline Slaughtering table & Staphylococcus aureus, Proteus mirabilis \\
\hline
\end{tabular}

Table 7: Antibiotics sensitivity patterns of Gram-positive bacterial isolates

\begin{tabular}{|c|c|c|c|c|c|c|}
\hline \multirow[t]{2}{*}{ Antibiotics } & \multicolumn{2}{|c|}{ Micrococcus luteus } & \multicolumn{2}{|c|}{ Staphylococcus aureus } & \multicolumn{2}{|c|}{ Bacillus spp. } \\
\hline & $\mathrm{IZ}(\mathrm{mm})$ & ITP & $\mathrm{IZ}(\mathrm{mm})$ & ITP & $\mathrm{IZ}(\mathrm{mm})$ & ITP \\
\hline Pefloxacin $(30 \mu \mathrm{g})$ & 0.0 & $\mathrm{R}$ & 10 & $\mathrm{R}$ & 17 & I \\
\hline Gentamycin $(10 \mu \mathrm{g})$ & 12 & $\mathrm{R}$ & 22 & I & 20 & $\mathrm{R}$ \\
\hline Erythromycin $(15 \mu \mathrm{g})$ & 8 & $\mathrm{R}$ & 20 & I & 0.0 & $\mathrm{R}$ \\
\hline Ciprofloxacin $(10 \mu \mathrm{g})$ & 0.0 & $\mathrm{R}$ & 24 & $\mathrm{~S}$ & 18 & I \\
\hline Streptomycin $(30 \mu \mathrm{g})$ & 0.0 & $\mathrm{R}$ & 0.0 & $\mathrm{R}$ & 0.0 & $\mathrm{R}$ \\
\hline Rocephin $(25 \mu \mathrm{g})$ & 14 & I & 12 & $\mathrm{R}$ & 14 & I \\
\hline Amoxicillin $(30 \mu \mathrm{g})$ & 0.0 & $\mathrm{R}$ & 0.0 & $\mathrm{R}$ & 0.0 & $\mathrm{R}$ \\
\hline Zinnacef $(25 \mu \mathrm{g})$ & 0.0 & $\mathrm{R}$ & 0.0 & $\mathrm{R}$ & 0.0 & $\mathrm{R}$ \\
\hline Ampiclox $(30 \mu \mathrm{g})$ & 15 & $\mathrm{R}$ & 0.0 & $\mathrm{R}$ & 0.0 & $\mathrm{R}$ \\
\hline Septrin $(30 \mu \mathrm{g})$ & 12 & I & 0.0 & $\mathrm{R}$ & 10 & $\mathrm{R}$ \\
\hline
\end{tabular}

Key: $\mathrm{R}=$ Resistant, $\mathrm{I}=$ Intermediate, $\mathrm{S}=$ susceptible, $\mathrm{IZ}(\mathrm{mm})$ = Inhibition Zone in millimeters, ITP = interpretation according to CLSI standard 
Olubukola Olayemi Olusola-makinde, Int. Ann. Sci.; Vol. 9, Issue 1, pp: 33-40, 2020

Table 8: Antibiotic sensitivity pattern for Gram negative bacterial isolates

\begin{tabular}{|c|c|c|c|c|c|c|c|c|c|c|}
\hline \multirow[t]{2}{*}{ Antibiotics } & \multicolumn{2}{|c|}{$\begin{array}{l}\text { Proteus } \\
\text { mirabilis }\end{array}$} & \multicolumn{2}{|c|}{$\begin{array}{l}\text { Proteus } \\
\text { vulgaris }\end{array}$} & \multicolumn{2}{|c|}{ Escherichia coli } & \multicolumn{2}{|c|}{$\begin{array}{l}\text { Enterobacter } \\
\text { aerogenes }\end{array}$} & \multicolumn{2}{|c|}{ Aeromonas spp. } \\
\hline & $\begin{array}{c}\mathrm{IZ} \\
(\mathrm{mm})\end{array}$ & ITP & $\begin{array}{l}\mathrm{IZ} \\
(\mathrm{m} \\
\mathrm{m})\end{array}$ & ITP & $\begin{array}{c}\mathrm{IZ} \\
(\mathrm{mm})\end{array}$ & ITP & $\mathrm{IZ}(\mathrm{mm})$ & ITP & $\mathrm{IZ}(\mathrm{mm})$ & ITP \\
\hline Pefloxacin $(30 \mu \mathrm{g})$ & 14 & I & 16 & $\mathrm{~S}$ & 17 & $\mathrm{~S}$ & 0.0 & $\mathrm{R}$ & 9 & $\mathrm{R}$ \\
\hline Amoxicillin $(30 \mu \mathrm{g})$ & 0.0 & $\mathrm{R}$ & 0.0 & $\mathrm{R}$ & 0.0 & $\mathrm{R}$ & 0.0 & $\mathrm{R}$ & 0.0 & $\mathrm{R}$ \\
\hline Gentamycin $(10 \mu \mathrm{g})$ & 0.0 & $\mathrm{R}$ & 0.0 & $\mathrm{R}$ & 16 & $\mathrm{~S}$ & 0.0 & $\mathrm{R}$ & 11 & $\mathrm{R}$ \\
\hline Ciprofloxacin $(10 \mu \mathrm{g})$ & 0.0 & $\mathrm{R}$ & 20 & $\mathrm{I}$ & 21 & $\mathrm{~S}$ & 18 & $\mathrm{I}$ & 18 & $\mathrm{I}$ \\
\hline Streptomycin $(30 \mu g)$ & 0.0 & $\mathrm{R}$ & 12 & I & 17 & $\mathrm{I}$ & 0.0 & $\mathrm{R}$ & 12 & I \\
\hline Septrin $(30 \mu \mathrm{g})$ & 12 & I & 15 & $\mathrm{I}$ & 19 & $\mathrm{~S}$ & 14 & I & 16 & $\mathrm{~S}$ \\
\hline Augmentin $(30 \mu \mathrm{g})$ & 0.0 & $\mathrm{R}$ & 8 & $\mathrm{R}$ & 14 & I & 0.0 & $\mathrm{R}$ & 10 & $\mathrm{R}$ \\
\hline Sparfloxacin $(10 \mu \mathrm{g})$ & 0.0 & $\mathrm{R}$ & 10 & $\mathrm{R}$ & 12 & $\mathrm{R}$ & 16 & $\mathrm{~S}$ & 13 & $\mathrm{I}$ \\
\hline Ofloxacin $(10 \mu \mathrm{g})$ & 10 & $\mathrm{R}$ & 0.0 & $\mathrm{R}$ & 0.0 & $\mathrm{R}$ & 0.0 & $\mathrm{R}$ & 8 & $\mathrm{R}$ \\
\hline Chloramphenicol $(30 \mu \mathrm{g})$ & 0.0 & $\mathrm{R}$ & 14 & $\mathrm{I}$ & 0.0 & $\mathrm{R}$ & 0.0 & $\mathrm{R}$ & 0.0 & $\mathrm{R}$ \\
\hline
\end{tabular}

Key: $\mathrm{R}=$ Resistant, I= Intermediate, $\mathrm{S}=$ susceptible, IZ $(\mathrm{mm})=$ Inhibition Zone in millimeters, ITP = interpretation according to CLSI standard

\subsection{Antibiotic sensitivity pattern of bacterial isolates from Onyearugbulem and FUTA abattoirs}

Tables 7 and 8 show the antibiotic sensitivity pattern of Gram positive and Gram-negative bacterial isolates from Onyearugbulem and FUTA abattoirs while the Multiple antibiotic resistance (MAR) index of bacterial isolates were shown in Table 9. Ciprofloxacin had an inhibitory effect on all the Gram positive bacterial isolates with the highest inhibitory activity on $S$. aureus at 24.00 $\mathrm{mm}$, and the Gram negative bacteria with the highest inhibitory activity on E. coli at $21.00 \mathrm{~mm}$. Micrococcus Sp had the highest MAR index (0.8) compared to Proteus Sp which had the lowest MAR index (0.5). The relatedness of the bacterial isolates with respect to antibiotic sensitivity was illustrated in Figure 1. Aeromonas Sp. and E. coli showed the closest relatedness according to Antibiotic Sensitivity.

Table 9: Multiple antibiotic resistance (MAR) index of bacterial isolates

\begin{tabular}{|c|c|c|}
\hline S/N & Bacterial isolates & MAR Index \\
\hline 1 & Micrococcus luteus & 0.8 \\
\hline 2 & Staphylococcus aureus & 0.7 \\
\hline 3 & Bacillus spp. & 0.6 \\
\hline 4 & Proteus mirabilis & 0.8 \\
\hline 5 & Proteus vulgaris & 0.5 \\
\hline 6 & Escherichia coli & 0.4 \\
\hline 7 & Enterobacter aerogenes & 0.7 \\
\hline 8 & Aeromonas spp. & 0.6 \\
\hline
\end{tabular}

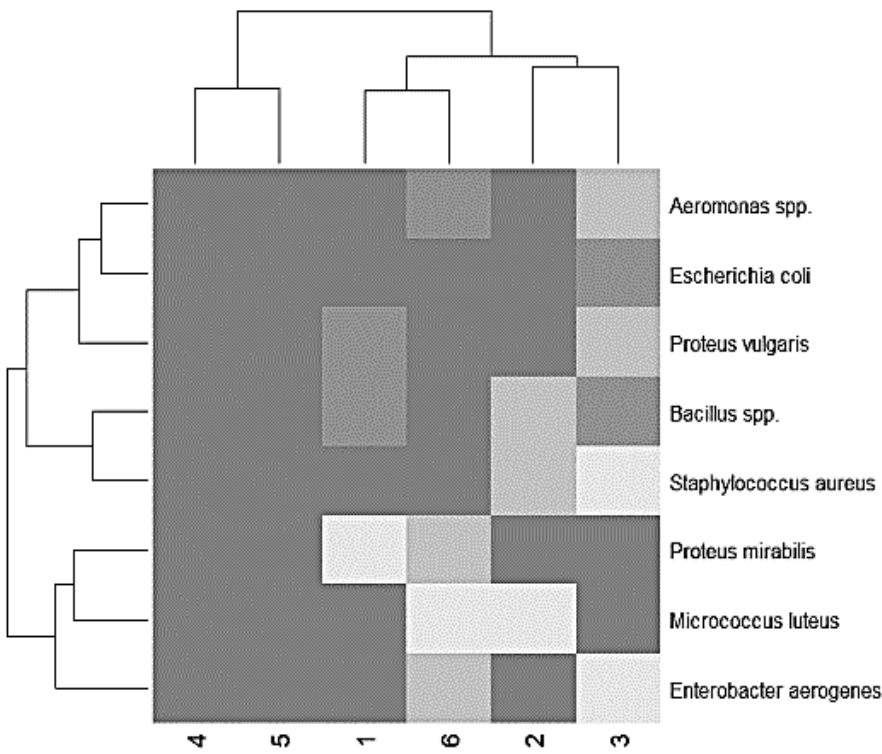

KEY: 1 = Pefloxacin $(30 \mu \mathrm{g}), 2=$ Gentamycin $(10 \mu \mathrm{g})$, 3 = Ciprofloxacin $(10 \mu \mathrm{g}), 4=$ Streptomycin $(30 \mu \mathrm{g})$, $5=$ Amoxicillin $(30 \mu \mathrm{g}), 6=$ Septrin $(30 \mu \mathrm{g})$

Figure 1: Antibiotics relatedness between bacterial isolates from abattoir

\section{Discussion}

As part of the basic requirement of life, clean air is a major necessity for wellbeing. The result from this study shows the array of bacteria associated with Onyearugbulem and FUTA abattoir. In this study, a high total bacterial count was observed at all the sampling points, especially the gutter (2.55 x $\left.10^{1} \mathrm{cfu} / \mathrm{ml}\right)$ and roof $\left(6.0 \times 10^{1} \mathrm{cfu} / \mathrm{ml}\right)$ of Onyearugbulem and FUTA abattoirs respectively. The different bacterial counts also varied among sample locations and the abattoirs as reported by 
Outdoor Air Quality and Antibiogram Characteristics of Bacterial Isolates of Akure City Abattoirs, Nigeria

Omoya et al. [8]. The high bacterial counts observed in this study shows presence of these organisms in the abattoir environment, or their facilities could be attributed to the fact that meat contains abundant nutrient requirements for the growth of microorganisms [3]. E. coli and Bacillus Sp were the most prevalent organisms observed during the course of this Study.

The morphological and biochemical tests revealed biodiversity of both Gram positive and Gramnegative bacteria with some pathogenic and others non-pathogenic. The bacteria presumptively identified in this study were Micrococcus Sp, Bacillus Sp, Staphylococcus aureus, Escherichia coli, Proteus Sp, Enterobacter aerogenes and Aeromonas Sp. These are similar to those reported by Omoya et al., [8] who isolated S. aureus, B. subtilis, Micrococcus Sp. and E. coli from aerosols of an abattoir in Akure, Nigeria. E. coli is an enteric bacterium that is accountable for the epidemic of diarrhea. Presence of E. coli anywhere is usually an indication of poor hygiene [5]. S. aureus can also result to a wide variety of diseases in man and animals by the synthesis of toxin. Staphylococcal toxins are known cause of food poisoning; this is because the toxins are produced by bacteria commonly found in inappropriately kept food items [5]. B. subtilis has been reported to cause disease in sternly immunecompromised patients. It causes food poisoning and chronic skin infection [17]. The presence of these bacteria in an abattoir environment depicts the poor state of hygiene and sanitary practices employed during the different stages of abattoir operations [18]. The possible sources of contaminants could be due to the unhygienic manner of handling meat in abattoirs, and the badly managed environments where animals are daily slaughtered and processed. The conventional antibiotics tested in this study were those frequently administered for animal production. In this study, ciprofloxacin had the highest inhibitory effect on both Gram positive and Gram-negative bacteria, and thus could be recommended to infected workers that are exposed to these bacterial isolates. Maron et al, [19] and Kang and So, [20] had reported the detection of multiantibiotic resistance by bacteria in the environment.

\section{Conclusions}

This study has shown the presence of both Gram positive and Gram-negative bacteria in the outdoor air of Onyearugbulem and FUTA abattoirs. The Antibiotic Sensitivity results pattern of the isolated microorganisms also revealed resistance of some of the isolates to known conventional antibiotics. The result clearly indicated that the cleaning procedures practised at the abattoirs are ineffective. This implies that such environment could be dangerous to human health. Therefore, the establishment should maintain proper and routine sanitization and hygiene practices.

\section{Competing Interests}

The author declared that no conflict of interest exists in the publication of this article.

\section{How to Cite This Article:}

O. Olusola-makinde, "Outdoor Air Quality and Antibiogram Characteristics of Bacterial Isolates of Akure City Abattoirs, Nigeria", Int. Ann. Sci., vol. 9, no. 1, pp. 3340, Nov. 2019. doi: 10.21467/ias.9.1.33-40

\section{References}

[1] Z. Andualem, Z, Gizaw, L. Bogale and H. Dagne, "Indoor bacterial load and its correlation to physical indoor air quality parameters in public primary schools," Multidiscipl Resp Med, 14, 2, 1-7, January 2019.

[2] H. M. Haynes, CRC Handbook of Chemistry and Physics, 97th edn. CRC Press, 2016-2017. ISBN-13: 9781498754286

[3] P. Srikanth, S. Sudharsanam and R. Steinberg. "BioAerosols in Indoor Environment: Composition, Health Effects and Analysis," Indian J Med Microbiol, 26, 4, 302-312, October 2008.

[4] V. Patella, G. Florio, D. Magliacane, A. Giuliano, M. A. Crivellaro and D. Di Bartolomeo, "Urban air pollution and climate change: "the Decalogue: allergy safe tree" for allergic and respiratory diseases care." Clin Mol Allergy, 16, 20, 1-12, September 2018.

[5] J. M. Willey, L. M. Sherwood and C. J. Woolverton. Prescott, Harley, and Klein's Microbiology, NY, McGraw Hill, 2008.

[6] H. Neboh, O. Ilusanya, C. Ezekoye and F. Orji, "Assessment of Ijebu Igbo Abattoir effluent and its impact on the ecology of the receiving soil and river." J Envtl Sci Tox Food Tech, 7, 5, 61-67, November 2013.

[7] S. Cabo Verde, S. M. Almeida, J Matos, D. Guerreiro, M. Meneses, T. Faria, D. Botelho, M. Santos and C. Viegas, "Microbiological assessment of indoor air quality at different hospital sites." Res. Microbiol, 166, 557-563, September 2015.

[8] F. O. Omoya, J. O. Obameso and T. A. Olukibiti, "Evaluation of Bacterial Composition of the Aerosol of 
Olubukola Olayemi Olusola-makinde, Int. Ann. Sci.; Vol. 9, Issue 1, pp: 33-40, 2020

Selected Abattoirs in Akure, South Western Nigeria," Intl J Bioengr L Sci, 8(4), 356-358, March 2014.

[9] Y. Titilawo, L. Obi and A. Okoh, "Antimicrobial resistance determinants of Escherichia coli isolates recovered from some rivers in Osun State, South-Western Nigeria: Implications for public health," Sci of the Total Envt, 523, 82-94, April 2015.

[10] B. C. Iweriebor, S. Gaqavu, L. C. Obi, U. U. Nwodo and A. I. Okoh, "Antibiotic Susceptibilities of Enterococcus Species Isolated from Hospital and Domestic Wastewater Effluents in Alice, Eastern Cape Province of South Africa." Intl J Envtl Res Pub Health, 12, 4231-4246, April 2015.

[11] J. F. Lindahl and D. Grace, The consequences of human actions on risks for infectious diseases: a review, Inf ecol epi, 5, 30048-30058, November 2015.

[12] P. O. Olutiola, O. Famurewa and H. G. Sonntag, "Introduction to General Microbiology: A practical approach.” 2nd edn, Bolabay Publication. 2000.

[13] G. Cheesbrough, Principles of sanitation. 3rd edn. Chapman and Hall, London. 2006.

[14] J. G. Cappuccino and N. Sherman, Microbiology: A Laboratory Manual, 8th edn Pearson, USA. 2008.

[15] Clinical Laboratory Standard (CLSI), Performance Standards for Antimicrobial Susceptibility Testing: Twenty-Fourth Informational Supplement, CLSI document M100-S24. Wayne, PA: Clinical and Laboratory Standards Institute, 2014.

[16] M. M. Mahroop Raja and S. John. "Multidrug Resistance Profile of Urinary Tract Infected Gram Positive Pathogenic Bacterial Isolates," Intl J Infect, 2, 1, 2277422779, January 2015.

[17] K. J. Ryan and C. G. Ray, $4^{\text {th }}$ edn, Sherris Medical Microbiology. McGraw Hill. 2004.

[18] O. O. Adekolurejo, G. T. Osho and A. Bakare, "Microbial Evaluation of Different Cleaning Techniques on Meat Contact Surfaces in an Abattoir in Akure, Nigeria," Appl Trop Agric, 21, 3, 223-228, December 2016.

[19] D. F. Maron, T. J. Smith and K. E. Nachman. Restrictions on antimicrobial use in food animal production: an international regulatory and economic survey. Glob Health, 9, 9-48, October 2013.

[20] C. H. Kang, Y. Shin, W. Kim, Y. Kim, K. Song, E. G. Oh, S. Kim, H. Yu and J. S. So. Prevalence and antimicrobial susceptibility of Vibrio parahaemolyticus isolated from oysters in Korea, Envtl Sci Poll Res Intl, 23, 918-926, January 2016.
Publish your research article in AIJR journals-

$\checkmark \quad$ Online Submission and Tracking

$\checkmark \quad$ Peer-Reviewed

$\checkmark \quad$ Rapid decision

$\checkmark \quad$ Immediate Publication after acceptance

$\checkmark \quad$ Articles freely available online

$\checkmark \quad$ Retain full copyright of your article.

Submit your article at journals.aijr.in

\section{Publish your books with AIJR publisher-}

$\checkmark \quad$ Publish with ISBN and DOI.

$\checkmark$ Publish Thesis/Dissertation as Monograph.

$\checkmark \quad$ Publish Book Monograph.

$\checkmark \quad$ Publish Edited Volume/ Book.

$\checkmark$ Publish Conference Proceedings

$\checkmark \quad$ Retain full copyright of your books.

Submit your manuscript at books.aijr.org 